\title{
The Role of Teacher Efficacy and Characteristics on Teaching Effectiveness, Performance, and Use of Learner-Centered Practices
}

\author{
Carlo Magno and Josefina Sembrano \\ De La Salle-College of Saint Benilde, Philippines
}

\begin{abstract}
The study tested two models on the interaction of teacher variables using Structural Equations Modeling (SEM). In the first model, the effect of teacher's personality characteristics and teaching efficacy on teacher's performance and effective teaching was tested. In the second model, the effects of learner-centered practices on teacher's performance, effective teaching, and teaching efficacy were included. 296 teachers from a community college were assessed by their students on their teaching performance using the Student Instructional Report (SIR), the Effective Teaching Inventory (ETI), and the Learner-centered Practices Questionnaire which were devised by the researchers. On the other hand, the teachers assessed themselves using Osgood's Personality Characteristics Scale and the Teacher Efficacy Inventory by Gibson and Dembo (1984). In the SEM analysis, the two models did not change on their measures of goodness of fit with a RMSEA of .045 indicating that both models have a rather good fit. It was found that the teachers practicing learner-centered approaches use their self-efficacy in order to be effective in teaching, but it was also found that being effective does not result in high teaching performance ratings. The use of learner-centered practices is seen as effective but does not warrant having high ratings based on student assessment.
\end{abstract}

A teacher's general performance in teaching is influenced by various internal and external factors. These different teaching factors are measured and assessed in order to come up with indicators of successful teaching that would effectively regulate students' learning and serve as success indicators for a school. Various studies have proposed different criteria on how to assess teaching performance and they differ according to different schools' specific objectives. However, in explaining teaching performance, there are important common factors that need to be considered. Teacher performance is influenced by the teachers' personality characteristics (Polk, 2006; Curtis \& Liying, 2001; Mullins, 1992; Hughes, Costner, \& Douzenis, 1988; Mayhew, 1986; Sherman \& Blackburn, 1975; Bridgwater, 1982) and their efficacy beliefs in teaching (Yeh, 2006; Fisler \& Firestone, 2006; Onafowora, 2005; Rogalla, 2004; Yoon, 2002; Weasmer \& Woods, 1998; Gibson \& Dembo, 1984). The studies investigating the effects of teachers' personal characteristics on teaching performance became few and far after the 1980's at which point no conclusions were arrived 
at because of the lack of coherence of the variables for personal characteristics.

On the other hand, the effect of teaching efficacy on teaching performance is established, although teaching performance has different constructs in studies investigating the effects of efficacy and personal characteristics of teachers. There is a need to further separate the different dimensions of teaching performance because the effects of personal characteristics and efficacy may vary according to different domains in assessing performance. Teaching performance in different studies may mean both effective and ineffective characteristics (Young \& Shaw, 1999). Effective characteristics of teachers consist of a different set of items as compared with general measures that assesses the level of teacher's performance in teaching (Magno, 2006a). For example, teaching methodologies and strategies may be effective or ineffective depending on the implementation of the teachers and hence, should only be used for general assessment and not for surveying the effective characteristics of teachers. Conversely, items on being "enthusiastic, well-prepared., genuine, selfconfident etc." are seen as positive and effective characteristics that exist in the relationship between the teacher and the student. In the study, teacher performance and effective teaching characteristics are separated where the former refers to the general rating of teachers using a scale and the latter is comprised of positive characteristics referring to the teacher.

Another educational outcome that has gained attention in recent studies on teaching effectiveness is the use of learner-centered practices. Being learner-centered in the course of teaching means providing the most supportive learning context for diverse students. In a learner-centered approach, the teacher understands and values student differences and needs (McCombs, 1997). Studies have shown that the use of learner-centered approaches inside the classroom has an impact on the personal efficacy of teachers (Sariscsany, 2005; Morrell \& Caroll, 2003; Yost, 2002; Cannon \& Scharmann, 1996). The present study tested a model on (1) the effect of learner-centered practices on teaching efficacy, (2) the effect of personal characteristics and teaching efficacy on teacher effectiveness and performance, and (3) the relationship of teaching efficacy and personal characteristics.

\section{Effects of Teaching Efficacy on Teaching Performance and Effectiveness}

The literature explaining the effects of teaching efficacy on teaching performance is established on the grounds of the social cognitive theory (Bandura, 1977). Bandura (1997) concluded that the evidence across studies is consistent in showing that "perceived self-efficacy" contributes significantly to level of motivation and performance accomplishments. Bandura (2000) embraced an integrated perspective for human performance in which social influences operate through psychological mechanisms. Teachers' own beliefs and convictions about their own performance have much influence on the actual performance (Magno, 2005; Jinks \& Morgan, 1999). It was explained by Gibson and Dembo (1984) that teachers who believe student learning can be influenced by effective teaching (outcomes expectancy beliefs) and who also have confidence in their own teaching abilities (self-efficacy beliefs) would persist longer, provide a greater academic focus in the classroom, and exhibit different types of feedback than teachers who have lower expectations concerning their ability to influence student learning. Enochs, Smith and Huinker (2000) were among those who contextualized self-efficacy for teaching. They explained that personal teaching efficacy has been defined as a belief in one's ability to teach effectively and teaching outcome expectancy as the belief that effective teaching will have a positive effect on student learning. Research on efficacy of teachers suggests that behaviors such as persistence on a task, risk taking, and use of innovations are related to degrees of efficacy (Ashton, 1985; Ashton \& Webb, 1986). For example, highly efficacious teachers have been found to be more likely to use inquiry and student- 
centered teaching strategies, while teachers with a low sense of efficacy are more likely to use teacher-directed strategies, such as lecture and reading from the text (Czerniak, 1990). In classrooms where teachers have high levels of teaching efficacy, high levels of learning occur (Weasmer \& Woods, 1998).

The research trend on teaching efficacy at the onset of the 21 st century concentrated more on establishing reliable and valid measures of selfefficacy contextualized in teaching and it was usually made domain specific, for instance, for mathematics and science teaching. One is the Science Teaching Efficacy Belief InstrumentPreservice (STEBI-B) by Enochs \& Riggs (1990) which was further enriched in the studies of Wingfield, Freeman, and Ramsey (2000), Tosun (2000), Bleicher (2001, 2002) and Bleicher and Lindgren (2002), and Settlage (2000). STEBI-B is a one-page, 23-item instrument containing items such as, "I will typically be able to answer students' science questions." Preservice teachers indicate that they either agree or disagree with such a statement by choosing from a 5-point Likert scale, ranging from strongly agree to strongly disagree. Their responses totaled over the 23 items provide a measure of their self-efficacy beliefs. Another version was also applied in mathematics by Enochs, Smith, and Huinker (2000). This time, each of the instruments was subject specific and had factorial validity established by a more rigorous confirmatory factor analysis, utilizing a structural modeling program. Across the studies, the two-factor structure remained stable proving that teaching efficacy is composed of personal efficacy and outcome. Thus, it is not only the effect of teaching efficacy on performance that is established, but also its factor structure.

\section{Effects of Personal Characteristics on Teaching Performance and Effectiveness}

There is a wide variation on how personality characteristics of teachers are conceptualized in different studies. Because of this wide array of differences, different components of personality characteristics have also been used. This is primarily due to a wide selection of theories explaining an individual's personality. For example (1) Grindler and Straton (1990), Grant \& Cambre (1990), and Katz (1992) used the Myers-Briggs Type Indicator (MBTI) results to help teachers develop different teaching methods and more readily accept a variety of materials and technology; (2) Henson and Chambers (2003) also used the factors of the MBTI to predict teaching efficacy and classroom control orientation; (3) Erdle, Murray, and Rushton (1985), Henry and Rohwer (2004), Murray, Rushton, and Paunonen (1990), and Teachout (1997) studied personality as a collective of individual behavior, such as ambition, intelligence, sense of humor, or others; (4) Madsen, Standley, and Cassidy (1989), and Yarbrough and Madsen (1998) operationalized personality as teacher intensity or enthusiasm. Despite the different ways of operationalizing personality as a variable among teachers, there is evidence of the relationship between personality of teachers and effective teaching. There are numerous studies showing that personality is a significant predictor of effective teaching (Krueger 1972; Murray, Rushton, \& Paunonen 1990; Schmidt, Lewis, \& Kurpius-Brock, 1991) although these studies are from latter years of the previous century and thus need to be established in the present period. There is a need to further investigate the impact of personality on effective teaching. According to Polk (2006) the personality of the teacher is a pervasive element in the classroom, and attention as to its impact on learning outcomes is well deserved.

\section{Relationship of Teaching Efficacy and Personal Characteristics}

There is consistent evidence that personality characteristics have an effect on teaching efficacy. In a recent study by Yeh (2006), it was found that 
teaching efficacy is a reliable predictor in the improvement of the personality characteristics of teachers. The findings suggest that personality types such as intrapersonal intelligence, criticalthinking dispositions, and a judicial thinking style results in a more reliable outcome in reflective teaching and mastery performance (which is selfefficacy). Moreover, the study of Flores and Clark (2004) found that personality (character), interests, occupational activity, interpersonal style, and moral worth using multivariate regression analysis showed an effect on teacher efficacy. Even studies that investigated the effect of teaching efficacy alone on performance recognized the need to see what propels teaching efficacy such as the study of Onafowora (2005) where she recommends that further investigation on novice teachers' "self" confidence at different times and to note consistency patterns, or growth as it relates to teacher-efficacy attributes. Fisler and Firestone (2006) further explained the role teacher factors play in classroom change and improvement. They found that individual teacher factors such as self-efficacy could mediate the influence on teacher learning and pedagogical change. However, the study of Henson and Chambers (2003) used personality types as predictors of self-efficacy and classroom control and in their findings using canonical analysis, the overall model was not significant and the effect for the first function was considered substantive. In their study it appeared that personality may not be as strongly related to efficacy. In the present study it is hypothesized that personal characteristics will have an effect on teaching efficacy as they lead to better teaching performance and effectiveness.

\section{Learner-Centered Practices}

Learner-centered practices have gained attention as a way of enhancing the outcomes of teaching and learning among students. There is a shift from a directive approach in teaching to recognizing more the needs of the learners. According to McCombs (1997) learner-centered is defined for the learner and the learning process as a positive learning environment that is created facilitating the success of students. There are 14 learner-centered psychological principles that were formulated by the American Psychological Association task force that are related to students' learning, motivation, and individual differences. The integrating factors that affect the learner and his learning are metacognitive and cognitive, affective, developmental, personal and social, and individual differences. The major features of learnercenteredness practices are: (1) the learners are included in the educational decision making process; (2) diverse perspectives of learners are encouraged; (3) individual differences of the learners are accounted for and respected; and (4) learners are co-creators of the teaching and learning process.

Much has been studied on the effects of learnercenteredness in the classroom setting focusing on student outcomes. There is a need to study how learner-centered practices interact with teacher factors such as teaching efficacy and performance. There is little evidence explaining the impact of using learner-centered practices on teaching efficacy; there is definitely a call for more studies in this line of research. One is Sariscsany's (2005) study on the influences of learning-centered methodologies on preservice teachers' personal teaching efficacy. In the study, students are engaged in a creative problem solving environment using games for understanding interjected between pre- and postmeasurement of teacher efficacy. Preliminary date analysis indicates a statistically significant $(\mathrm{p}<.05)$ gain in teaching efficacy from pre- to post-test scores. This finding also indicates that preservice teachers with higher levels of teaching efficacy attribute their gains to a number of active rather than passive instructional strategies used within the course.

Yeung \& Watkins (2000) mentioned in their study that experiences of teaching practice, electives, pupils, and teaching practice supervisors (Electives) are the major sources for the development of a sense of teaching efficacy. Although it was not exactly mentioned that learner-centered practices affects teaching efficacy, the discussion provided by Yeung \& 


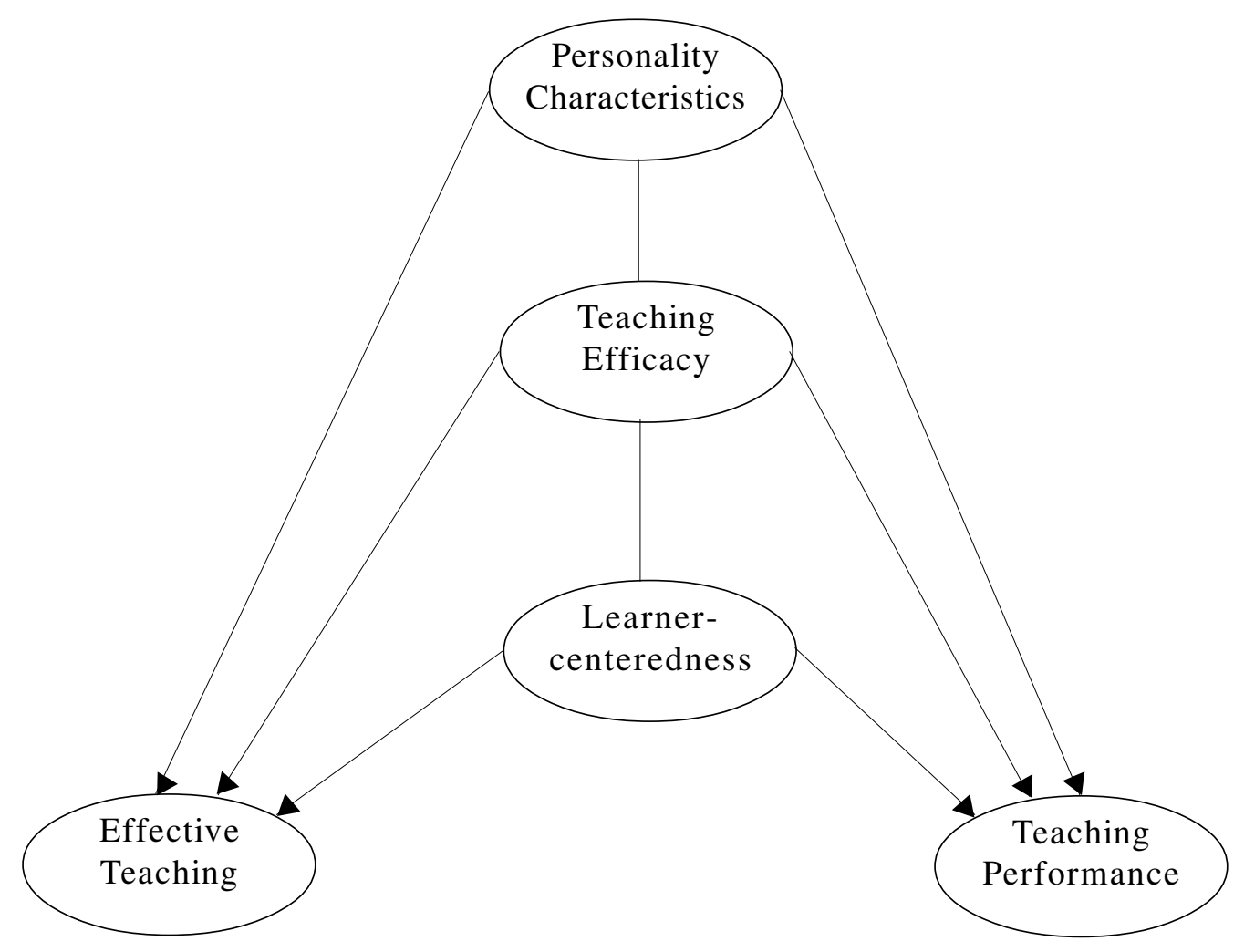

Figure 1. Diagram Showing the Connections of Teacher Factors Leading to Teaching Performance and Teaching Effectiveness.

Watkins (2000) explains the direction of learnercenteredness leading to teaching efficacy.

\section{Teaching Performance and Effectiveness}

There is a growing call for teacher evaluation to focus not only on teacher-related behaviors but also to translate it into student outcome (Ellet \& Teddle, 2003; Ovando, 2001). The most widelyused measures of teacher performance are composed of multiple dimensions and used factor analysis to arrive at sources of variation (Pike, 1998; Allison-Jones \& Hirt, 2004; Howard, Helms, \& Lawrence, 1997, Centra, 1998; Scriven, 1994; Li-Ping Tang, 1997; Marsh \& Bailey, 1993; Young \& Shaw, 1999; Heckert, Latier, Ringwald, \& Silvey, 2006; Stringer \& Irwing, 1998; Wanous $\&$ Hudy, 2001). The most typical function of teacher performance is to serve as an indicator of school success and for the promotion of teachers, thereby improving teaching and personnel decisions (Magno \& Tangco, 2006; Magno, 2006b; Staples, 1998; Szeto, 1995). There is a marked difference on how teacher performance is measured with the components of measuring teacher effectiveness. Teacher performance includes measures of general teaching practices such as teaching methods and strategies, classroom management, planning and organization of teaching. Often, the results of these measures are used for promotion and feedback. The measures for performance are interpreted as levels where teachers achieve to a certain degree the criteria specified (Centra, 1998). Teacher effectiveness on the other hand is composed of characteristics that discriminates good teachers from bad teachers (Young \& Shaw, 1999). The content of teacher effectiveness includes some aspects of the 
teachers' personality that are necessary in teaching such as being tolerant, having a good sense of humor, being warm and friendly, and being concerned about students. This distinction between performance and effectiveness is not yet well-defined in literature. Studies use these concepts interchangeably due to the nature of their seeming relationship, where teacher performance is rated highly and hence must be effective.

\section{CONCEPTUAL FRAMEWORK}

The study tested a model showing the effect of personality characteristics of teachers on their performance in teaching, effective teaching characteristics, and teaching efficacy. This is explained in Bandura's social cognitive theory (1977, 1986) where personal beliefs are concerned with the conviction that one can successfully execute the behavior required to produce the outcomes such as teacher performance. Changes in the teachers' effort and achievement are attributed to the way they conceptualize themselves (Gorrell, 1990). Personality plays a role in the way teachers are rated on their teaching performance and their being effective in teaching. The behavior attributed to good teaching coincides with certain personal characteristics such as being friendly, approachable, warm, kind, appreciative, and inspiring (Young \& Shaw, 1999). This is explained in the personal constructs theory where each person construes (interprets) and anticipates the occurrence of events in accordance with his own construction system of constructs (Kelly, 1955). The effect of personality on teaching, effective teaching characteristics, and teaching efficacy is studied together since the effect of personality alone on teaching is not yet conclusive (Murray et al., 1990). Certain personality characteristics allow a teacher to be effective and to be rated highly by their students (Young \& Shaw, 1999, Szeto, 1995).
The effect of learner-centeredness used by teachers on self-efficacy, performance and effective teaching characteristics are also tested in a model. These connections are anchored on the social cognitive theory (Bandura, 1977, 1986) where the teachers' belief of their behavior (self-efficacy) lead to certain outcomes (teaching performance and teaching effectiveness). The influence of learnercentered practices on teaching efficacy is explained in the outcome expectancy model of Bandura (1977) where teachers believe that the environment can be controlled and their abilities bring about positive student change. Learner-centeredness is suitable in the model because its design is consistent with the current views of learning, motivation, and individual differences where teachers can best create an ideal learning environment by supporting the learning context (McCombs, 1997). The social cognitive theory, when applied to teaching, explains that teachers using authentic and student-directed activities such as learner-centered practices develop the conviction to be successful and thus perform well (Sariscsany, 2005). The use of a learner-centered approach in teaching enables the teacher to be more effective and perform better (Yeung \& Watkins, 2000).

The evidence across different studies is consistent in showing that "perceived self-efficacy" contributes significantly to level of motivation and performance accomplishments.

\section{METHOD}

\section{Participants}

A sample of 297 teaching faculty and 7,093 students from a community college participated in this study. The list of all teaching faculty for the first term, school year 2006-2007 was obtained to randomly select the faculty members to be included in the sample. After the random selection of faculty members, one class was randomly selected for each faculty member. Out of the 297 selected faculty members, 55 were full-time faculty members while the rest $(N=242)$ were teaching on a part-time basis. 


\section{Instruments}

Five instruments were used in the study: The Osgood's Personality Characteristics Scale (OPCS), Teacher Efficacy Inventory (TEI), Effective Teaching Inventory (ETI), Student Instructional Report (SIR), and Learner-Centered Practices Questionnaire (LCPQ).

Osgood's Personality Characteristics Scale (OPCS). The OPCS was used to measure the personality characteristics of teachers as developed by Sherman and Blackburn (1975). They were able to extract four factors composed of 22 items using orthogonal rotation as a result of their factor analysis. The factors are four distinct personality components: personal potency (items 1-8), pragmatism (9-10), amicability (11-15), and intellectual competency (16-22). The items under the four personality components are bipolar adjective-pair items descriptive of various personality characteristics. Based on Sherman and Blackburn's (1975) study, the descriptions of the factors are as follows:

(1) Personal potency - Factor loadings ranged from .84 to .54 . One with high personal potency is characterized as one who is highly attractive and who, by virtue of this attractiveness, is able to exert considerable influence over his students. Such a person is a dynamic, outgoing individual, who, at the same time communicates well with students and has a relaxed attitude.

(2) Pragmatism - High levels in this factor indicate a common sense or down-to-earth dimension to the teaching situation, which students perceive as an important ingredient in effectiveness. The factor loadings of the items are .73 and .75.

(3) Amicability - Describes an individual in terms of his friendliness and goodwill towards others. There is interpersonal sensitivity reflected in this factor. Factor loadings are from .76 to .72.

(4) Intellectual competency - This factor reflects expertise, knowledge, wisdom, decisiveness, stability, rational, and sensible behavior. Factor loadings range from .47 to .85 .
The instrument had an overall internal consistency of .887 using Cronbach's alpha.

Teacher Efficacy Inventory (TEI). The TEI was used to measure teaching efficacy. This instrument was constructed by Gibson and Dembo (1984) and they were able to extract two factors. Factor 1 is called Personal Teaching Efficacy (items 1 to 9), which reflects the teacher's sense of personal responsibility in student learning and/or behavior and corresponds to Bandura's selfefficacy dimension. Factor 2 is called Teaching Efficacy (items 10 to 16), which represents how a teacher's belief that his or her ability can bring about change is significantly limited by factors external to the teacher such as external environment, family background, and parental influences. Analysis of internal consistency reliability yielded a Cronbach's alpha coefficient of .78 for the Personal Teaching Efficacy factor, .75 for the Teaching Efficacy factor and .79 for all the items. For each item the students responded using an 8-point scale ranging from strongly agree to strongly disagree. The overall internal consistency of the items using Cronbach's alpha is .806 .

Effective Teaching Inventory (ETI). The ETI was constructed by Young and Shaw (1999) and was used to measure effective teaching characteristics. The items were based on extensive literature on student evaluation and effective teaching. The measure is composed of 20 items. The items are unidimensional since only one factor was extracted using principal component analysis. All items, including the global measure, were rated using a scale from 1 to 9 , where 1 is "not at all descriptive," and 9 is "very descriptive." The items were able to discriminate between effective and ineffective teachers. The discrimination function generated using the items predicted group membership $97 \%$ correctly for the ineffective teachers and $99 \%$ for the effective teachers. The overall internal consistency reliability of the items using Cronbach's alpha is .994. 
Student Instructional Report (SIR). The SIR was used to assess the performance of teachers in five areas: Classroom organization, classroom resources, response to student needs, evaluation, and enrichment activities. The items of the SIR were based on the Student Instructional Report 2 by Centra (1998) of the Educational Testing Service. In the ETS version the Cronbach's alpha was uniformly high ranging from .89 to .98. In the current study the Cronbach's alpha value obtained was .998 indicating that the items are highly consistent. Interclass correlations were also conducted having acceptable correlation coefficients. In Centra's SIR, a study of several multiple section courses did demonstrate that learning gains were related to the overall evaluation of the instructor as well as to some of the scale scores as evidence of criterion validity. The construct validity is demonstrated where the factors produced closely duplicated the scales designed. However, the scales did correlate significantly with each other, as has been typical of other student rating forms, and this reflects a response set by students. That is, students have a tendency to rate good instructors as effective on all items and scales rather than differentiating their performances. A confirmatory factor analysis was conducted in the preset study to prove the factor structure of the SIR.

\section{Learner-Centered Practices Questionnaire} ( $L C P Q)$. The LCPQ is based on the principles of the learner-centered practices by McCombs (1997). The items were constructed under the areas of (1) positive interpersonal characteristics (items 1 to 5), (2) encourages personal challenge (items 6 to 10), (3) adopts class learning needs (items 11-15), and (4) facilitates the learning process (items 16 to 19). The overall reliability of the scale is .994 indicating high internal consistency of the items. The description and scale reliability for the areas are as follows:

\section{Table 1}

\section{Mean and Standard Deviation.}

\begin{tabular}{lccccc}
\hline & M & Scale & S D & SE & N \\
\hline Personality Characteristics & & & & & \\
$\quad$ Personal Potency & 5.42 & 7 & 7.22 & 0.42 & 296 \\
$\quad$ Pragmatism & 5.20 & 7 & 2.09 & 0.12 & 296 \\
$\quad$ Amicability & 5.88 & 7 & 4.46 & 0.26 & 296 \\
$\quad$ Intellectual Competency & 5.04 & 7 & 5.31 & 0.31 & 296 \\
Teacher Efficacy & & & & & \\
$\quad$ Personal Efficacy & 4.88 & 6 & 6.28 & 0.36 & 296 \\
$\quad$ Teaching Efficacy & 3.66 & 6 & 5.86 & 0.34 & 296 \\
Student Instructional Report & & & & & \\
SIR-Part 1 & 3.98 & 5 & 0.38 & 0.02 & 296 \\
SIR-Part 2 & 4.11 & 5 & 0.42 & 0.02 & 296 \\
SIR-Part 3 & 4.08 & 5 & 0.43 & 0.03 & 296 \\
SIR-Part 4 & 4.13 & 5 & 0.42 & 0.02 & 296 \\
SIR-Part 5 & 4.07 & 5 & 0.42 & 0.02 & 296 \\
Effective Teaching Inventory & & & & & \\
$\quad$ Effective Teaching & 7.50 & 9 & 16.62 & 0.97 & 296 \\
Overall Effectiveness & 7.52 & 9 & 0.89 & 0.05 & 296 \\
Learner-Centered Practices & & & & & \\
$\quad$ Positive Interpersonal Characteristic & 7.49 & 9 & 4.64 & 0.27 & 296 \\
$\quad$ Encourages Personal Challenge & 7.43 & 9 & 4.16 & 0.24 & 296 \\
Adapts Learning Needs & 7.25 & 9 & 4.69 & 0.27 & 296 \\
Facilitates the Learning Process & 7.36 & 9 & 3.73 & 0.22 & 296 \\
\hline
\end{tabular}

Note. SIR-Part 1-Classroom Organization, Part2-Use of classroom resources, Part 3-Response to student needs, Part 4Evaluation, Part 5-Enrichment Activities. 
(1) Positive interpersonal characteristics the items reflect the ability to develop positive interpersonal relationships with students and the instructor's ability to value and respect students as persons. The internal consistency of the items using Cronbach's alpha is .986.

(2) Encourages personal challenge - the items show how students are expected to take charge of their learning. The internal consistency of the items using Cronbach's alpha is .983.

(3) Adopts class learning needs - the items shows the ability to be flexible in order to address students' needs. The internal consistency of the items using Cronbach's alpha is $\mathbf{9 7 5}$.

(4) Facilitates the learning process - the items reflect the instructor's ability to encourage students to monitor their own learning process. The internal consistency of the items using Cronbach's alpha is .990 .

The confirmatory factor analysis conducted proved the factor structure of the four areas of learner-centered practices.

\section{Procedure}

Individual letters were circulated to the faculty members to formally inform them about the study being conducted prior to the actual administration of the survey instruments to their selected classes. The letter also indicated the date and time of the survey administrations. The administration of the two sets of instruments (First wave: Osgood's Personality Characteristics Scale and Learner Centered Practices Questionnaire; Second wave: Teaching Efficacy Inventory, Student Instructional Report, Effective Teaching Inventory) took place on two different time frames. In the community college sampled, the students evaluate their teachers on a regular basis during the $8^{\text {th }}$ to $9^{\text {th }}$ week of the term using the Student Instructional Report questionnaire (SIR). During the study's run, the ETI was administered together with the administration of the SIR. The faculty on the other hand completed the Osgood's Personality Characteristics Scale during the first wave and Teaching Efficacy Inventory on the second wave outside of the classroom while the students were responding to the other set of instruments.

\section{Data Analysis}

The mean and the standard deviation were used to report the levels of each of the scales. All the factors of the measures were intercorrelated to establish the relationship of the factors to be entered in the Structural Equations Modeling.

The Structural Equations Modeling or SEM was used as the major analysis in the study. Two models were tested in the study. In the first model, the effects of personality characteristics on teaching efficacy, effective teaching, and teaching performance were tested. The effect of learnercentered practices on teaching efficacy was also tested. In Model 2, the same paths were tested but this time the effects of learner-centered practices on effective teaching and teaching performance were tested. The obtained Root Mean Square Error Approximation (RMSEA) was used to determine the best fitting model, as well as measures of noncentrality and single sample fit indices. Single sample goodness of fit indices were also used to evaluate the models (Joreskog GFI/AGFI, Akaike Information Criterion, Schwarz's Bayesian Criterion, Browne-Cudeck Cross Validation Index, Bentler-Bonett, James-Mulaik-Brett Parsimonious Fit Index, and Bollen's Rho).

The Sobel test was used to test for mediation effects. The study further tested whether the latent factors carry the effect of a given exogenous latent variable to an endogenous latent variable. The Sobel values were likewise tested for significance.

\section{RESULTS}

In the analysis, the mean and the standard deviation were used to determine the levels of the factors and intercorrelation of the factors are conducted to establish the relationship and the patterns that exist in among the factors.

All of the factors for the measures were intercorrelated (see Appendix A). In the correlation matrix, all of the factors of the SIR, effective 


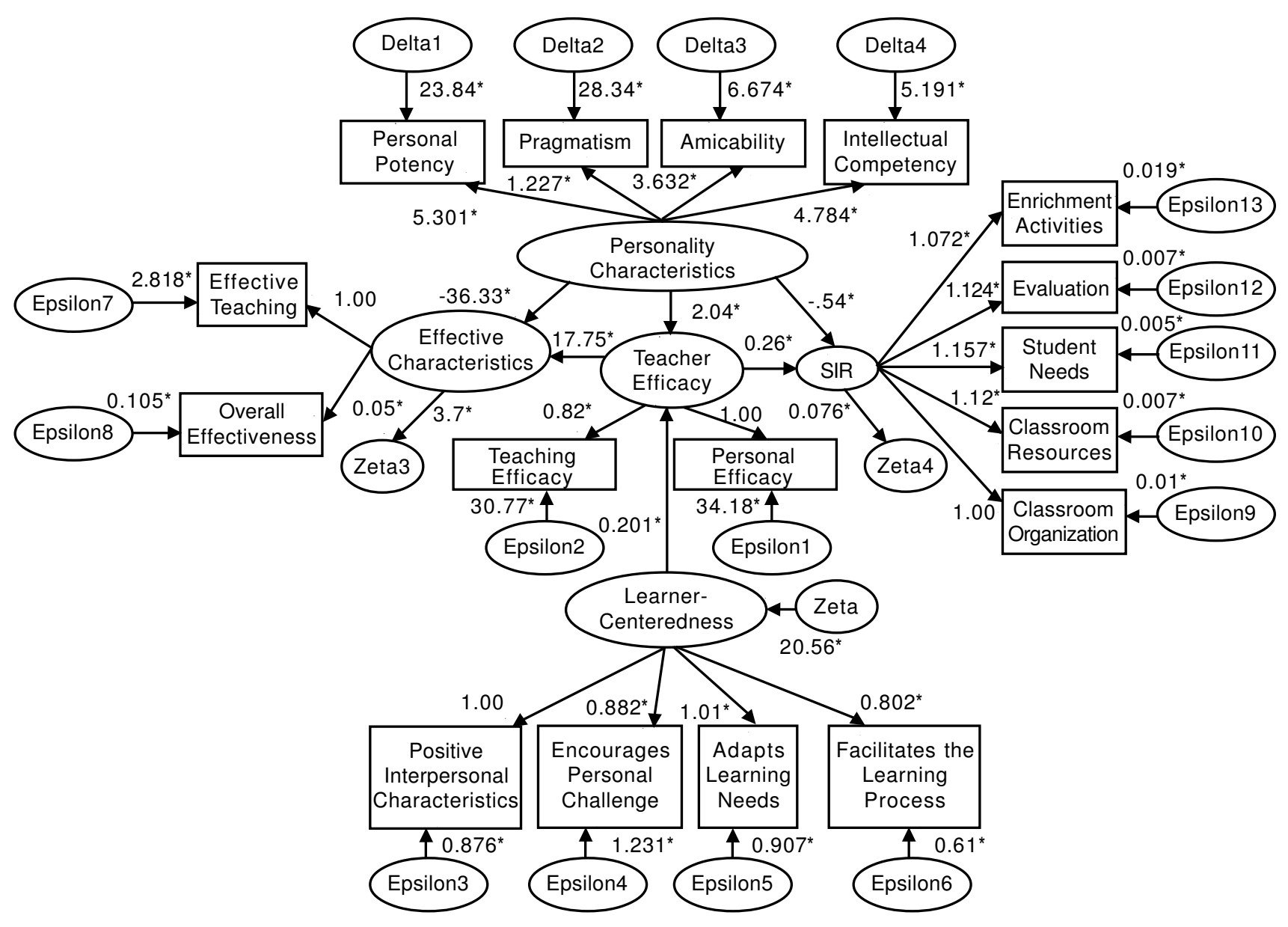

Figure 2. Model 1

teaching characteristics, and learner-centered practices were not significantly correlated with all of the factors of teaching characteristics (personal potency, pragmatism, amicability, intellectual competency) and personal efficacy. The factors of SIR, effective teaching characteristics, learner-centeredness and teaching efficacy were all significantly intercorrelated with each other, $p<.01$. All the factors of personality characteristics also had significant intercorrelations, $p<.05$. Among the other factors, only personal efficacy was significantly related with the personality characteristics. There emerged a pattern in the correlations showing that the personal characteristics were not related with the performance measures.
The first model proposed shows the effect of (1) personality characteristics on teaching efficacy, SIR, effective characteristics, and (2) the effect of using learner centered practices on teaching efficacy. The second model is the same as model 1 with the addition of effects of learnercenteredness on teacher performance and teaching effectiveness are added.

In model 1, the RMSEA obtained was .045 which indicates that the factors show a rather good fit. The goodness of fit based on the computed chisquare $\left(c^{2}=245.46, d f=113\right)$ was significant, $p<.05$. The results of the noncentrality fit indices based on the population covariance using the McDonald Noncentrality Index (0.744), Population Gamma Index (0.935), and Adjusted Population Gamma Index (0.912) have high 
values consistent with the RMSEA indicating a rather good fit.

In model 2, most of the parameters for goodness of fit were the same with those of model 1 . The RMSEA obtained was also .045 indicating a rather good fit. The values of the noncentrality fit indices for model 2 were also the same with model 1 . For the measures of single sample fit indices as shown in Table 2, there were no changes on the estimates from model 1 to model 2 . Since the only difference in model 2 is that the effects of learner-centeredness on teaching efficacy, teaching effectiveness, and SIR are included, restricting three more effects among the latent variables does not change the goodness of fit of the model.

Model 1 shows that all the factors of each latent variable and the errors for each manifest variable are significant. This means that the proposed factors are significant components of the construct measured. As proposed, all effects of one latent factor on another have significant paths. The present study shows that (a) personality characteristics have a significant direct effect on teacher efficacy, effective characteristics and SIR, $\mathrm{p}<.05$; (b) teacher efficacy has a significant direct effect on effective characteristics and SIR, $\mathrm{p}<.05$; and (c) learner-centeredness has a significant effect on teacher efficacy, $\mathrm{p}<.05$. However, personality characteristics have a negative effect on effective characteristics and the SIR. By looking at the items of the personality characteristics, the more teachers show the characteristics on the left side of the scale (indicating low scores), the more they use learnercentered practices and gain high ratings in their SIR.

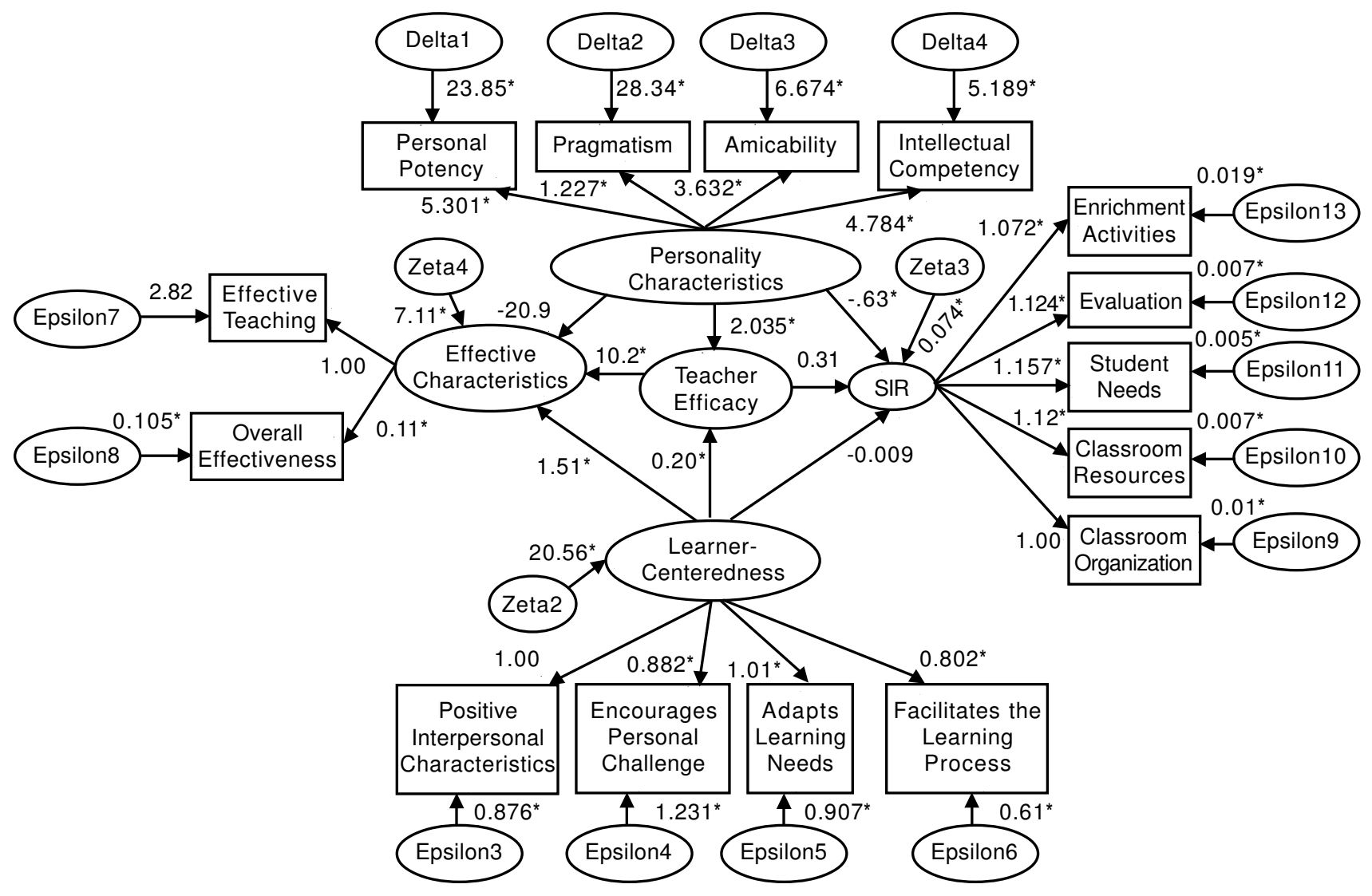

Figure 3. Model 2 


\section{Table 2}

\section{Single Sample Fit Indices}

\begin{tabular}{lrr}
\hline & Model 1 & Model 2 \\
\hline & & \\
Joreskog GFI & 0.913 & 0.913 \\
Joreskog AGFI & 0.882 & 0.882 \\
Akaike Information Criterion & 1.103 & 1.103 \\
Schwarz's Bayesian Criterion & 1.604 & 1.604 \\
Browne-Cudeck Cross Validation Index & 1.121 & 1.121 \\
Independence Model Chi-Square & 7695.830 & 7695.830 \\
Independence Model df & 136.000 & 136.000 \\
Bentler-Bonett Normed Fit Index & 0.968 & 0.968 \\
Bentler-Bonett Non-Normed Fit Index & 0.979 & 0.979 \\
Bentler Comparative Fit Index & 0.982 & 0.982 \\
James-Mulaik-Brett Parsimonious Fit Index & 0.804 & 0.804 \\
Bollen's Rho & 0.962 & 0.962 \\
Bollen's Delta & 0.982 & 0.982 \\
\hline
\end{tabular}

The characteristics on the left side of the scale are (1) bold, aggressive, extrovert, active, energetic, strong, good communicator, and relaxed for personal potency; (2) practical and predictable for pragmatism; (3) sensitive, open-minded, accepting, reasonable, and gracious for amicability; and (4) expert, knowledgeable, wise, decisive, stable, rational, and sensible for intellectual competency. The direct effect of personality characteristics on the SIR and effective teaching characteristics are negative but when mediated by teaching efficacy, the effect is positive. In testing whether personality characteristics have a significant indirect effect using the Sobel test, the value obtained was 2.86 which is significant, $p<.05$. Personality characteristics also have a significant indirect effect on the SIR obtaining a Sobel value of 2.81, $p<.05$. This shows that self-efficacy significantly mediates the effect of personality characteristics on SIR and effective teaching characteristics.

In model 2, the effect of learner-centeredness on the SIR and effective teaching characteristics were added. In the same way, personality characteristics had a negative significant direct effect on SIR and a positive significant direct effect on teaching efficacy. However, the effect of personality characteristics on effective teaching no longer appeared to be significant. The teacher's personality on the left scale has no bearing on being an effective teacher, but teachers can still be rated highly on their performance (SIR) and it helps build their teaching efficacy. The use of learner-centered practices in teaching has a significant direct effect on teaching efficacy and effective teaching characteristics but not on the SIR. A teacher who uses a learner-centered approach in teaching obtains efficacy in teaching and becomes effective. Teaching efficacy has a significant direct effect on effective teaching characteristics but not on the SIR.

The difference of model 2 from model 1 is that in model 2, when the effects of learner-centered practices (on the SIR and teaching effectiveness) are included, the direct effect of personality characteristics on teaching effectiveness is no longer significant. However in model 1, without the effects of learner-centeredness, the effect of personality characteristics is significant for teaching effectiveness.

Though in model 2, personality characteristics have no direct effect on effective teaching, in both models, efficacy can serve as a significant mediating 
variable between personality characteristics and teaching effectiveness, $p<.05$.

Learner-centeredness has no significant direct effect on the SIR and when mediated by efficacy, it still has no significant indirect effect. The use of learner-centered practices has a significant indirect effect on effective teaching characteristics but only when mediated by teaching efficacy (Sobel $=2.84$, $p<.05)$.

\section{DISCUSSION}

The results of the study showed that the personality characteristics of a teacher influences his teaching performance (SIR), effective teaching characteristics, and teaching efficacy. Teaching efficacy also mediates the effect of personality on the SIR and effective teaching characteristics. When learner-centered practices are used, a teacher becomes effective although it does not follow that his or her performance will be rated high. Teaching efficacy moderates the effect of learner-centeredness on effective teaching characteristics.

The findings of the study support previous studies demonstrating the effect of personality characteristics on assessment of teaching performance (SIR), effective teaching characteristics, and teaching efficacy (Polk, 2006; Curtis \& Liying, 2001; Mullins, 1992; Hughes, Costner, \& Douzenis, 1988; Mayhew, 1986; Sherman \& Blackburn, 1975; Bridgwater, 1982). It was found in the study that teachers manifesting bold, aggressive, extrovert, active, energetic, strong, good communicator, relaxed, practical, predictable, sensitive, open-minded, accepting, reasonable, gracious, expert, knowledgeable, wise, decisive, stable, rational, and sensible behaviors tend to be rated highly on their teaching performance as measured by the SIR. This supports the findings of Henson and Chambers (2003) that certain personality types exhibit better self-efficacy and classroom performance. Few previous studies have actually generated explanations for teacher behavior and the effects of personality and efficacy on performance and have not been able to explain the dynamics of the outcome. In the current study, it is shown that when these types of teachers make use of leanercentered approaches in teaching, a teacher needs to believe in his teaching abilities in order to be effective in teaching, but being effective in this sense does not entail the teacher garnering high performance ratings. This shows that using learnercentered practices are seen as effective but it may not be favorable for students.

The study showed that it is not merely the use of learner-centeredness in teaching that enables teachers to perform better but more so his or her personality and efficacy. Learner-centeredness is not working out as intended. Given the current system of teaching and evaluation in the sampled community college, to perform well based on student ratings, what counts more is the teacher's efficacy and personality. The findings also show the possibility that teachers are not effectively carrying out the principles of learner-centeredness as set by the APA. Applying a learner-centered approach enables a teacher to view learning in terms of looking into the needs and learning process of the students. The learner-centered variable not translating into teacher performance shows that the teachers have a limited view of learning (Fischler, 1999; Levitt, 2002; Orton, 1996).

The students, upon rating the teacher, do not look entirely at the teaching processes used by the teacher such as learner-centeredness, but rather, they look at the personality that goes along with these processes. In forms such as the SIR then, it is possible that students generally rate the teacher's personality and not his or her actual performance. This explains a great deal why certain personality types perform better in teaching.

The findings show that there is a marked gap between learner-centeredness and performance ratings of teachers using the SIR. It is generally supposed that a teacher using learnercenteredness performs better in teaching and as such, this area needs to be explored more in future studies. Current studies only translate and explain the effect of learner-centeredness on 
student outcomes and not really on teaching performance per se because learnercenteredness is assumed to be equated with performance-and this assumption is not supported in this study. The items of the SIR may not fit well with the use of learnercenteredness and other measures of performance can be used in future studies. Learner-centeredness having no effect on teaching performance seems to show that the students do not see the learner-centeredness of the teacher translated in their teaching. This phenomenon of learner-centeredness having an effect on effective teaching and not on performance further bolsters the existence of a distinction between the two constructs.

Given the findings of the study, it is recommended that the principles of learnercenteredness and items on teaching effectiveness in the current teacher performance measures to be integrated. The use of learner-centeredness is ideal in classroom situations and the teacher assessment tools needs to be able to capture it. To train teachers to enhance their personality in order to be more accepting in the use of authentic pedagogies such as learner-centeredness is vital given the findings that effective teaching strategies coincide with certain teachers' personality types. It is recommended for potential researchers to conduct an in-depth study on the nature of students as raters to determine if their culture and orientation (and other student factors) affect the way they rate the teachers. It is also important to include a measure of teaching efficacy in the screening process and hiring of teachers.

\section{AUTHOR NOTE}

The data used in the study is part of a research project at the Center for Learning and Performance and Assessment of De La Salle-College of Saint Benilde. Special thanks to the staff of the Performance Assessment Services Unit for conducting the data gathering and Ms. Nicole Tangco for editing the manuscript.
Correspondence can be addressed to Carlo Magno at the Center for Learning Performance and Assessment, De La Salle - College of St. Benilde, 2544 Taft Avenue, Malate, 1004 Manila (e-mail: magnoc@dls-csb.edu.ph) or to Josefina Sembrano with the same address (e-mail: sembranoj@dlscsb.edu.ph).

\section{REFERENCES}

Allison-Jones, L.L. \& Hirt, J. B. (2004). Comparing the teaching effectiveness of part-time $\&$ full-time clinical nurse faculty. Nursing Education Perspectives, 25, 238-242.

Ashton, P. T. ( 1985). Motivation and the teacher's sense of efficacy. In C. Ames \& R. Ames (Eds.), Research on motivation in education: Vol. 2. The classroom milieu (pp. 141-174). Orlando, FL: Academic Press.

Ashton, P. T., \& Webb, R. B. (1986). Making a difference: Teachers' sense of efficacy and student achievement. New York: Longman.

Bandura,A. (1977). Self-efficacy: Toward a unifying theory of behavioral change. Psychological Review, 84, 191-215.

Bandura, A. (1986). Social foundations of thought and action: A social cognitive theory. Englewood Cliffs, N.J.: Prentice-Hall.

Bandura, A. (1997). Self-efficacy: The exercise of control. New York: W.H. Freeman.

Bandura, A. (2000). Self-efficacy: Foundation of agency. In W. Perrig \& A. Gorb (Eds.), Control of human behavior, mental processes, and consciousness (pp. 17-33). Mahwah, NJ: Lawrence Erlbaum.

Bleicher, R.E. (2001, March). Building science teaching confidence in preservice elementary teachers. Paper presented at the annual meeting of the National Association of Research in Science Teaching Association, St. Louis, MO.

Bleicher, R.E. (2002, April). Increasing confidence in preservice elementary teachers. Paper presented at the annual 
meeting of the American Educational Research Association, New Orleans, LA.

Bleicher, R.E., \& Lindgren, J. (2002). Building confidence in preservice elementary science teachers. In P. Rubba, W. DiBiase, \& B. Crawford (Eds.), Proceedings of the 2002 Annual International Conference of the Association for the Education of Teachers in Science (pp 1549-1562). ERIC Document Reproduction Service No. ED 465 602.

Bridgwater, C. A. (1982). Personality characteristics of ski instructors and predicting teacher effectiveness using the PRF. Journal of Personality Assessment, 46, 164-168.

Cannon, J. R. \& Scharmann, L. D. (1996). Influence of a cooperative early field experience on preservice elementary teachers' science selfefficacy. Science Education, 80, 419.

Centra, J. A. (1998). The development of the student instructional report II. Princeton, NJ: Educational Testing Service.

Curtis, A. \& Liying, C. (2001). Teachers' selfevaluation of knowledge, skills and personality characterstics needed to manage change. Asia - Pacific Journal of Teacher Education, 29, 139-143.

Czerniak, C. M. (1990, April). A study of self efficacy, anxiety, and science knowledge in preservice elementary teachers. Paper presented at the annual meeting of the National Association for Research in Science Teaching, Atlanta, GA.

Ellet, C. D. \& Teddle, C. (2003). Teacher evaluation, teacher effectiveness and school effectiveness: Perspective from the USA. Journal of Personnel Evaluation in Education, 17, 101-128.

Enochs, L. G., \& Riggs, I. M. (1990). Further development of an elementary science teaching efficacy belief instrument: A preservice elementary scale. School Science and Mathematics, 90, 695-706.

Enochs, L. G., Smith, P. L., Huinker, D. (2000). Establishing factorial validity of the mathematics teaching efficacy beliefs instrument. School Science and Mathematics, 100, 194-203.

Erdle, S., Murray, H. G., \& Rushton, J. P. (1985). Personality, classroom behavior, and student ratings of college teaching effectiveness: A path analysis. Journal of Educational Psychology, 77, 394-407.

Fischler, H. (1999). The impact of teaching experiences on student-teachers' and beginning teachers' conception of teaching and learning science. In J. Loughnan (Ed.), Researching teaching: Methodologies and practices for understanding pedagogy (pp. 172-197). London: Falmer Press.

Fisler, J. L. \& Firestone, W. A. (2006). Teacher learning in a school-university partnership: Exploring the role of social trust and teaching efficacy beliefs. Teachers College Record, 108, 1155-1186.

Flores, B., \& Clark, E. R. (2004). A critical examination of normalistas' selfconceptualization and teacher-efficacy. Hispanic Journal of Behavioral Sciences, 26, 230.

Gibson, S., \& Dembo, M. H. (1984). Teacher efficacy: A construct validation. Journal of Educational Psychology, 76, 503-511.

Grant, M.B., \& Cambre, M.A. (1990). Research on teachers' characteristics in relation to a cognitive-learning based interactive videodisc system. Paper presented at the Annual Meeting of the American Educational Research Association. Boston, MA.

Grindler, M.C., \& Straton, B.D. (1990). Type indicator and its relationship to teaching and learning styles. Action in Teacher Education, 7, 31-34.

Gorrell, J. (1990). Some contribution of selfefficacy research to self-concept theory. Journal of Research and Development in Education, 23, 73-81.

Heckert, T. M., Latier, A.., Ringwald, A., \& Silvey, B. (2006). Relation of course, instructor, and student characteristics to dimensions. College Student Journal, 40, $1-11$. 
Henry, W., \& D. A. Rohwer. 2004. University teachers' perceptions of requisite skills and characteristics of effective music teachers. Journal of Music Teacher Education, 13, 18-27.

Henson, R. K., \& Chambers, S. M. (2003). Personality type as a predictor of teaching efficacy and classroom control in emergency certification teachers. Education, 124, 261.

Howard, F. J., Helms, M. M., \& Lawrence, E. P. (1997). Development and assessment of effective teaching: an integrative model for implementation in schools of business administration. Quality Assurance in Education, 5, 159-161.

Hughes, T. M., Costner, M. J., \& Douzenis, C. (1988). Personality and Motivation Variables in Tomorrow's Teachers: A Center of Excellence. Education, 108, 393-400.

Jinks, J. \& Morgan, V. (1999). Children's perceived academic self-efficacy: An inventory scale. Teacher Journals, 72, 224-230.

Katz, Y.J. (1992). Toward a personality profile of successful computer-using teacher. Educational Technology, 32, 39-40.

Kelly, G. A. (1955). The psychology of personal constructs, tool. 1: A theory of personality. New York: WW Norton and Company.

Krueger, R. J. (1972). A predictive investigation of personality and music teaching success. Council for Research in Music Education Bulletin, 30, 11-17.

Levitt, K. E. (2002). An analysis of elementary teachers' beliefs regarding the teaching and learning of science. Science Education, 5, 177229.

Li-Ping Tang, T. (1997). Teaching evaluation at a public institution of higher education: Factors related to the overall teaching effectiveness. Public Personnel Management, 26, 379-380.

Madsen, C. K., J. M. Standley, \& J. W. Cassidy. (1989). Demonstration and recognition of high and low contrasts in teacher intensity. Journal of Research in Music Education, 37, 85-92.

Magno, C. \& Tangco, N. (2006). A metaevaluation study on the assessment of teacher performance in De La Salle-College of Saint Benilde (Tech. Rep. No. 2). Manila, Philippines:
De La Salle-College of Saint Benilde, Center for Learning Performance and Assessment.

Magno, C. (2005). The role of metacognitive regulation and learning approach on achievement and its effect on academic selfefficacy. Paper presented at the Annual Psychological Association of the Philippines, Baguio, Philippines.

Magno, C. (2006a). Program evaluation of the civic welfare training services of De La SalleCollege of Saint Benilde SY 2005 - 2006 (Tech. Rep. No. 3). Manila, Philippines: De La SalleCollege of Saint Benilde, Center for Learning Performance and Assessment.

Magno, C. (2006b). Factors of teacher Assessment (Tech. Rep. 4). Manila, Philippines: De La SalleCollege of Saint Benilde, Center for Learning Performance and Assessment.

Marsh, H. W. \& Bailey, M. (1993). Multidimensional students' evaluations of teaching effective. The Journal of Higher Education, 64, 1-18.

Mayhew, L. B. (1986). Personality and teaching. Journal of Communication,2, 83-89.

McCombs, B. L. (1997). Self-assessment and reflection: Tools for promoting teacher changes toward learner-centered practices. NASSP Bulletin, 81, 587-600.

Morrell, P. D. \& Carroll, J. B. (2003). An extended examination of preservice elementary teachers' science teaching self-efficacy. School Science and Mathematics, 103, 246-249.

Mullins, S. S. (1992). Qualities of the great teachers. The Instrumentalist, 46, 17-25.

Murray, H. G., J. P. Rushton, and S. V. Paunonen. 1990. Teacher personality traits and student instructional ratings in six types of university courses. Journal of Educational Psychology, 82, 250-61.

Murray, H. G., Rushton, J. P. \& Paunonen, S. V. (1990). Teacher personality traits and student instructional ratings in six types of university courses. Journal of Educational Psychology, 82, 250-261.

Orton, R. E. (1996). How can teacher beliefs about student learning be justified? Curriculum Inquiry, 26, 133-146. 
Onafowora, L. L. (2005). Teacher Efficacy Issues in the Practice of Novice Teachers. Educational Research Quarterly, 28, 34-44.

Pike, C. K. (1998). A validation study of an instrument designed to measure teaching effectiveness. Journal of Social Work Education, 34, 261-272.

Polk, J. A. (2006). Traits of effective teachers. Arts Education Policy Review, 107, 23-30.

Rogalla, M. (2004). Future problem solving program coaches' efficacy in teaching for successful intelligence and their patterns of successful behavior. Roeper Review, 26, 175.

Sariscsany, M. J. (2005). Influences of learningcentered methodologies on preservice teachers' personal teaching efficacy and learning outcomes. Research Quarterly for Exercise and Sport, 76, 88-90.

Schmidt, C. P., B. E. Lewis, and M. J. Kurpius-Brock. 1991. Relationships between teacher personality and ratings of applied music teaching behavior. Contributions to Music Education, 18, 20-35.

Scriven, M. (1994). Duties of as teacher. Journal of Personnel Evaluation in Education, 8, 151184.

Settlage, J. (2000). Understanding the learning cycle: Influences on abilities to embrace the approach by preservice elementary school teachers. Science Education, 84, 43-50.

Sherman, B. R. \& Blackburn, R. T. (1975). Personal characteristics and teaching effectiveness of college faculty. Journal of Educational Psychology, 67, 124-131.

Staples, R. W. (1994). Relationship of attitudes, perceptions and practices of students and teachers as evaluators of educational quality. Unpublished doctoral dissertation, The University of Texas at Austin.

Stringer, M. \& Irwing, P. (1998). Students' evaluations of teaching effectiveness: A structural modeling approach. British Journal of Educational Psychology, 68, 409-511.

Szeto, W. (1995). Perceptions of the purposes, approaches and uses of faculty performance evaluation among faculty across academic disciplines at a selected university. Unpublished doctoral dissertation, The University of Southern Mississippi.

Teachout, D. J. (1997). Preservice and experienced teachers' opinions of skills and behaviors important to successful music teaching. Journal of Research in Music Education, 45, 41-50.

Tosun, T. (2000). The impact of prior science course experience and achievement on the science teaching self-efficacy of preservice elementary teachers. Journal of Elementary Science Education, 72, 21-31.

Wanous, J. P. \& Hudy, M. J. (2001). Single-item reliability: A replication and extension. Organizational Research Methods, 4, 361-389.

Weasmer, J. \& Woods, A. M. (1998). I think I can: The role of personal teaching efficacy in bringing about change. The Clearing House, 71, 245-248.

Wingfield, M.E., Freeman, L., \& Ramsey, J. (2000, April). Science teaching self-efficacy of first year elementary teachers trained in a site based program. Paper presented at the annual meeting of the National Association for Research in Science Teaching, New Orleans, LA. (ERIC Document Service No. ED 439 956).

Yarbrough, C., \& K. Madsen. (1998). The evaluation of teaching in choral rehearsals. Journal of Research in Music Education, 46, 469-81.

Yeh, Y. (2006). The interactive effects of personal traits and guided practices on preservice teachers' changes in personal teaching efficacy. British Journal of Educational Technology, 37, 513.

Yeung, K. \& Watkins, D. (2000). Hong Kong student teachers' personal construction of teaching efficacy. Educational Psychology, 20, 213-236.

Yoon, J. S. (2002). Teacher characteristics as predictors of teacher-student relationships: Stress, negative affect, and self-efficacy. Social Behavior and Personality, 30, 485-494.

Yost, R. (2002). I think I can: Mentoring as a means of enhancing teaching efficacy. The Clearing House, 75, 195-198.

Young, S. \& Shaw, D. G. (1999). Profiles of effective college and university teachers. The Journal of Higher Education, 70, 670-687. 
Appendix A

Intercorrelations of the Factors of Personality Characteristics, Teaching Efficacy, Effective Teaching, and Learner Centeredness

\begin{tabular}{|c|c|c|c|c|c|c|c|c|c|c|c|c|c|c|c|c|c|}
\hline & \multicolumn{4}{|c|}{ Personality Characteristics } & \multicolumn{2}{|c|}{ Teaching Efficacy } & \multicolumn{5}{|c|}{ Teacher Performance } & \multicolumn{2}{|c|}{$\begin{array}{c}\text { Effective Teaching } \\
\text { Characteristics }\end{array}$} & \multicolumn{4}{|c|}{ Learner-Centered } \\
\hline & $\begin{array}{l}\text { Personal } \\
\text { Potency }\end{array}$ & Pragmatism & Amicability & $\begin{array}{l}\text { Intellectual } \\
\text { Competency }\end{array}$ & $\begin{array}{l}\text { Personal } \\
\text { Efficacy }\end{array}$ & $\begin{array}{l}\text { Teaching } \\
\text { Efficacy }\end{array}$ & $\begin{array}{l}\text { SIR- } \\
\text { Part } 1\end{array}$ & $\begin{array}{l}\text { SIR- } \\
\text { Part } 2\end{array}$ & $\begin{array}{l}\text { SIR- } \\
\text { Part } 3\end{array}$ & $\begin{array}{l}\text { SIR- } \\
\text { Part } 4\end{array}$ & $\begin{array}{l}\text { SIR- } \\
\text { Part } 5\end{array}$ & $\begin{array}{l}\text { Effective } \\
\text { Teaching }\end{array}$ & $\begin{array}{c}\text { Overall } \\
\text { Effectiveness }\end{array}$ & $\begin{array}{c}\text { Positive } \\
\text { Interpersonal } \\
\text { Relationship }\end{array}$ & $\begin{array}{l}\text { Encourages } \\
\text { Personal } \\
\text { Challenge }\end{array}$ & $\begin{array}{l}\text { Adapts } \\
\text { Learning } \\
\text { Needs }\end{array}$ & $\begin{array}{l}\text { Facilitates } \\
\text { the Learning } \\
\text { Process }\end{array}$ \\
\hline $\begin{array}{l}\text { Personal } \\
\text { Potency }\end{array}$ & 1.00 & & & & & & & & & & & & & & & & \\
\hline Pragmatism & $0.40^{* *}$ & 1.00 & & & & & & & & & & & & & & & \\
\hline Amicability & $0.61^{* *}$ & $0.52^{* *}$ & 1.00 & & & & & & & & & & & & & & \\
\hline $\begin{array}{l}\text { Intellectual } \\
\text { Competency }\end{array}$ & $0.67^{* *}$ & $0.53^{* *}$ & $0.73^{* *}$ & 1.00 & & & & & & & & & & & & & \\
\hline $\begin{array}{l}\text { Personal } \\
\text { Efficacy }\end{array}$ & $0.28^{* *}$ & $0.23^{* *}$ & $0.24^{* *}$ & $0.34^{* *}$ & 1.00 & & & & & & & & & & & & \\
\hline $\begin{array}{l}\text { Teaching } \\
\text { Efficacy }\end{array}$ & $0.14^{* *}$ & 0.09 & $0.19^{* *}$ & $0.24^{* *}$ & $0.24^{* *}$ & 1.00 & & & & & & & & & & & \\
\hline SIR-Part 1 & 0.03 & 0.03 & 0.01 & -0.01 & -0.03 & $0.19^{* *}$ & 1.00 & & & & & & & & & & \\
\hline SIR-Part 2 & 0.05 & 0.00 & 0.04 & 0.00 & -0.03 & $0.19^{* *}$ & $0.95^{* *}$ & 1.00 & & & & & & & & & \\
\hline SIR-Part 3 & 0.05 & 0.02 & 0.02 & -0.01 & -0.02 & $0.22^{* *}$ & $0.96^{* *}$ & $0.96^{* *}$ & 1.00 & & & & & & & & \\
\hline SIR-Part 4 & 0.03 & 0.02 & 0.02 & -0.01 & 0.00 & $0.20^{* *}$ & $0.94^{* *}$ & $0.96^{* *}$ & $0.96^{* *}$ & 1.00 & & & & & & & \\
\hline SIR-Part 5 & 0.06 & 0.01 & 0.04 & 0.00 & -0.01 & $0.21^{* *}$ & $0.91^{* *}$ & $0.93^{* *}$ & $0.93^{* *}$ & $0.93^{* *}$ & 1.00 & & & & & & \\
\hline $\begin{array}{l}\text { Effective } \\
\text { Teaching }\end{array}$ & 0.04 & 0.03 & 0.00 & 0.01 & 0.08 & $0.21^{* *}$ & $0.65^{* *}$ & $0.63^{* *}$ & $0.66^{* *}$ & $0.64^{* *}$ & $0.57^{* *}$ & 1.00 & & & & & \\
\hline $\begin{array}{l}\text { Overall } \\
\text { Effectiveness } \\
\text { Positive }\end{array}$ & -0.01 & 0.05 & -0.01 & 0.00 & 0.08 & $0.20^{* *}$ & $0.62^{* *}$ & $0.60^{* *}$ & $0.62^{* *}$ & $0.61^{* *}$ & $0.56^{* *}$ & $0.93^{* *}$ & 1.00 & & & & \\
\hline $\begin{array}{l}\text { Interpersonal } \\
\text { Relationship } \\
\text { Encourages }\end{array}$ & 0.01 & 0.03 & 0.02 & 0.00 & 0.09 & $0.22^{* *}$ & $0.64^{* *}$ & $0.62^{* *}$ & $0.65^{\star *}$ & $0.64^{* *}$ & $0.55^{* *}$ & $0.95^{* *}$ & $0.89^{* *}$ & 1.00 & & & \\
\hline $\begin{array}{l}\text { Personal } \\
\text { Challenge } \\
\text { Adapts }\end{array}$ & 0.02 & 0.00 & -0.01 & -0.01 & 0.05 & $0.19^{* *}$ & $0.62^{* *}$ & $0.59^{* *}$ & $0.62^{* *}$ & $0.61^{* *}$ & $0.53^{* *}$ & $0.96^{* *}$ & $0.88^{* *}$ & $0.93^{* *}$ & 1.00 & & \\
\hline $\begin{array}{l}\text { Learning } \\
\text { Needs }\end{array}$ & 0.02 & 0.04 & 0.03 & 0.02 & 0.07 & $0.23^{* *}$ & $0.64^{* *}$ & $0.61^{* *}$ & $0.65^{\star *}$ & $0.63^{* *}$ & $0.55^{* *}$ & $0.95^{\star *}$ & $0.90^{* *}$ & $0.96^{* *}$ & $0.94^{* *}$ & 1.00 & \\
\hline $\begin{array}{l}\text { Facilitates the } \\
\text { Learning Process }\end{array}$ & ss 0.06 & 0.03 & 0.04 & 0.02 & 0.08 & $0.22^{\star *}$ & $0.64^{* *}$ & $0.62^{* *}$ & $0.65^{* *}$ & $0.64^{* *}$ & $0.55^{\star *}$ & $0.95^{\star *}$ & $0.88^{* *}$ & $0.96^{* *}$ & $0.94^{* *}$ & $0.96^{* *}$ & 1.00 \\
\hline
\end{tabular}

Note. SIR-Part 1-Classroom Organization, Part 2-Use of classroom resources, Part 3-Response to student needs, Part 4-Evaluation, Part 5-Enrichment Activities. 